\title{
Pesquisa, produção de conhecimento, implicações práticas: estamos avançando?
}

http://dx.doi.org/10.1590/1807-55092014000300359

No editorial publicado no número 2 da RBEFE, de 2014, foram levantadas algumas questóes pertinentes à produção científica da nossa área acadêmica e a alguns aspectos inerentes a essa produção. Essas questōes são essenciais para o avanço sustentado da área e especialmente para a consolidação da identidade acadêmica, e, portanto, devem fazer parte de nossas discussóes, de forma regular e de maneira comprometida. As questóes formuladas incluíam, entre outras, reflexões acerca da produçáo do conhecimento específico na área de Educação Física e Esporte, do papel das agências de fomento e dos programas de Pós-graduação nesse cenário da produção de conhecimento específico da área, e ainda, indagações, por exemplo, sobre o efeito da abertura de Editais para o Esporte de Alto Rendimento e seus critérios (ou falta deles?) para avaliar a "relevância" dos projetos da área. Será que estamos caminhando na direção correta para a solidificação de uma identidade acadêmica e garantindo a proteção da integridade de nossa disciplina? Uma das perguntas norteadoras do editorial se referia ao "futuro de nossa área enquanto área acadêmica”. É imperativo que a comunidade científica siga discutindo e refletindo sobre essas questóes que, por sua vez, mesmo que ainda não sejam totalmente e satisfatoriamente respondidas, poderiam auxiliar na construçáo de um caminho mais sustentável e profícuo no sentido da produçáo de conhecimento da área. Adicionalmente, é papel dos pesquisadores da Educação Física e do Esporte guiarem investigaçóes e inovaçóes que em um futuro próximo poderiam ser "transferidas" para o mundo real, contribuindo, portanto, de forma significativa, não somente para o avanço do conhecimento, mas também, para o avanço da área profissionalizante, cuja prática baseada em evidência deveria ser uma premissa. Profissionais preparados para consumirem pesquisa de qualidade e pesquisadores contribuindo efetivamente para o avanço do conhecimento específico são situaçôes absolutamente fundamentais para o crescimento da Educação Física e Esporte, tanto enquanto área de atuação, como no que se refere à produçáo do conhecimento propriamente dito. Devemos, enquanto pesquisadores, trabalhar cada vez mais com os professores de Educação Física, Profissionais de Educação Física e do Esporte, em diferentes instâncias (escolar, alto rendimento, esporte de formação, etc.), buscando ser cada vez mais críticos com os dados coletados, fazendo perguntas de pesquisa que realmente importam para esse contexto, contextualizando essas informaçóes com o auxílio dos profissionais que vivem o diaa-dia da Educação Física e do Esporte. Assim, poderemos ampliar a utilidade da informação gerada, estreitar as relaçóes com o "consumidor final" do conhecimento que geramos na academia, garantir a integridade de nossa disciplina acadêmica e, ainda, manter a qualidade da produção de nossa área, que indiscutivelmente, já alcançou um elevado patamar. É missão e responsabilidade dos periódicos, editores, revisores, autores, órgáos de fomento de pesquisa, programas de Pós-Graduação, e comunidade científica-acadêmica em geral, garantir a sustentação desse cenário, cada um de acordo com suas respectivas açóes e prerrogativas. Certamente, resultados favoráveis irão emergir.

\section{Prof. Dr. Alexandre Moreira}

Blog da RBEFE - http://rbefe.blogspot.com.br Facebook - http://www,facebook.com/reveefe Twitter - https://twitter.com/RBEFE 